\title{
SUSTAINABILITY LEVEL OF DENSELY POPULATED AREA: JATIMULYO URBAN COMMUNITIES, LOWOKWARU DISTRICT, MALANG CITY
}

\author{
S Hariyani ${ }^{1}$, E B Kurniawan ${ }^{1}$, F Usman ${ }^{1}$, and F Shoimah ${ }^{1}$
}

Received: 14 September 2019 Accepted: 29 November 2019

\begin{abstract}
Large cities still peak the interests of some Indonesian society. Big city development as the center of economic activity is a powerful pull for society, influencing high workforce from both inside and outside of the city, causing a strong current of urbanization. One main problem that always accompanies urban areas development is density population. Urbanization has caused a very rapid explosion in the city population; one implication is the clumping workforce in large Indonesian cities. The high number of people who choose to settle in the city increase the number of both legal and illegal settlements. In the high-density settlement, many houses are not liveable and irregular. The densely populated settlements find many houses unfit for habitation and irregular. The research aims to formulate the sustainability level of Urban communities, Lowokwaru District, Malang City using quantitative method through sustainability level calculation. Jatimulyo Urban Communities is measured by the sustainability criteria of density, diversity, mixed-use, and compactness to formulate the related sustainable urban spatial structure. Interpretation of the calculation results references similar research. The calculation result shows that Jatimulyo Urban Communities is included in the moderate sustainability level, where density is moderate (101.1-200 people/ha), has a moderate building density (20-40 buildings/ha), has a random diversity level (1.0) and an entropy index (0.51), and compactness is near perfect inequality (Gini Coefficient 0.99).
\end{abstract}

\section{INTRODUCTION}

Economic and employment growth drives the rate of urbanization. The rate of savings and capital investment feeds into an expansion of the building stock and land-use conversion, as both a supply-side push factor of production and a demand-side pull by consumers. Economic structures and employment patterns also affect the trends of periurbanization. Business and technology affect not only employment but supply chain logistics, the distribution of production, services, and consumption (Korcelli, 2011)

Urban built structures and infrastructure are the components of the physical urban system. The floor space per person for living and working and the land intensity of such floor space, are the primary determinants, especially when household size is taken into account. The pattern of housing investment, housing form, community services, settlement density, and morphology are all relevant to the growth and pattern of peri-urban development. Transport and communications are the other key factors, as infrastructure can encourage or inhibit urban/rural migration, counter-urbanization, or re-urbanization. Transport is not only a matter of direct expansion: there has been a systemic change from a public transport-based radial pattern, to car and highway based network pattern (Jacobs, 2011)

\footnotetext{
${ }^{1}$ Departement of Urban and Regional Planning, Faculty of Engineering, Universitas Brawijaya
} 
Large cities still interest some parts of Indonesian society. Big city development as the center of economic activity is a powerful pull for society, influencing high workforce from both inside and outside of the city, causing a strong current of urbanization. One main problem that always accompanies urban areas development is density population. Urbanization has caused a very rapid explosion in the city population; one implication is the clumping workforce in large Indonesian cities. The high number of people who choose to settle in the city increase the number of both legal and illegal settlements. In the high-density settlement, many houses are not liveable and irregular (Djakapermana, 2008)

To overcome the problem of inefficiency in the provision of facilities and infrastructures by means of non-centralized city development, the existence of utility networks and infrastructure constructed with the concentric pattern from the city center to the fringe areas will encourage the physical development of a compact and continuous city in all directions of the periphery. This condition in the future allows the efficiency of financing in the provision of urban space infrastructure. Urban development as described above encourages sustainable urban spatial structures (Azman, 2006)

The problem faced by Malang City is the development of the population and the high flow of urbanization. Increased urban population increases the community's need for housing, offices, and other socio-economic facilities. These problems resulted from the development problems of Malang City, primarily related to the development of urban spatial structures including inequality of urban development, including the settlements dissemination pattern and centralization of public facilities. The research aims to formulate the sustainability level of Jatimulyo Urban Communities, Lowokwaru District, Malang City using quantitative method through sustainability level calculation. Jatimulyo Urban Communities is measured by the sustainability criteria of density, diversity, mixed-use, and compactness to formulate a related sustainbale urban spatial structure.

\section{Density}

Density is the ratio of the population or building unit to the area. The effect of density on sustainability occurs through differences in density, land use for housing, roads, and urban infrastructure. The relationship between density and urban character is also based on a feasible limit concept: at a certain density (threshold), whether the population within a territory produce the required interaction to run the functions of urban or activity properly. High density and integrated land use will encourage social interaction through compactness. Increasing city density and improving the quality of the downtown, will optimize land within the city (Djakapermana, 2008). The higher the population density in a region, the more sustainable the development. The higher the density of buildings or the higher the population density within a region, the more sustainable the development (Kenworthy, 2006)

Density is a critical typology in determining sustainable urban forms. It is the ratio of people or dwelling units to the land area. The relationship between density and urban character is also based on the concept of viable thresholds: at certain densities (thresholds), the number of people within a given area becomes sufficient to generate the interactions needed to make urban functions or activities viable. (Jabareen, 2006)

\section{Diversity}

The diversity of activities is the essence of sustainable cities. The diversity criteria are based on variations of housing type, building density, household size, age, culture and community income. If the diversity is high, then the sustainability of a region will also be high

The diversity of activity is essential to the sustainability of cities. The diversity dimension is subsequently adopted and widely accepted by many planning approaches, such 
as new urbanism, smart growth, and sustainable development. Lack of concentrated diversity can push people to use cars for almost all their needs. In dense, diversified city areas, people still walk, an activity that is impractical in the suburbs and most grey areas. The more intensely various and close-grained the diversity in an area, the more people walk. Even people who come into a lively, diverse area from outside, whether by car or by public transportation, walk when they get there. Diversity is vital; without it, the urban system declines as a living place and a place to live (Jabareen, 2006)

\section{Compactness}

The concept of compactness is applied to direct urban development on the existing city structures, thus minimizing energy for transportation, urban facilities, and infrastructure. The intensification of urban development is the main strategy to achieve compactness, building density and activities so that ultimately urban land use becomes more efficient and more sustainable. Compaction is an essential typology for achieving sustainable cities where sustainable cities have compact, solid, diverse and integrated features (Acioly Jr, 2000)

Compactness of the built environment is a widely accepted strategy through which more sustainable urban forms might be achieved. Compactness also refers to urban contiguity (and connectivity), which suggests that future urban development should take place adjacent to existing urban spatial structures. When the concept is applied to existing rather than new urban fabric, the containment of further sprawl, rather than the reduction of the present sprawl, is referred. Compactness of urban spatial can minimize the transport of energy, water, materials, products, and people. (Jabareen, 2006)

\section{METHODS}

Quantification of variable value data on urban spatial structures, especially on variables of diversity, gap, and compactness. The methods used include:

\section{Gini Coefficient}

Gini coefficient analysis method aims to determine the inequality or gap in a region, especially Jatimulyo Urban Communities [10]. Gini coefficient is a number or index that shows spatial inequality. The value/index of the Gini coefficient lies between 0 which is perfectly equal to 1 which is of perfect inequality [10]. Gini coefficient analysis method uses the following formula.

$$
\mathrm{GC}=0,5 \sum_{\mathrm{i}=1}^{\mathrm{N}}\left|\mathrm{X}_{\mathrm{i}}-\mathrm{Y}_{\mathrm{i}}\right|
$$

Information:

$\mathrm{Xi}$ The value of spatial variables, in the study, used the percentage of area in the i-th class

Yi: The value of variables to be measured by the level of the gap. The study used the cumulative percentage of the total population in the i-th class

\section{Entropy Index}

The entropy index is a measure of sustainability based on mix land use. The more diverse the land use of a region, the higher the region's sustainability level in supporting activities (Gemilang, 2008). The formula of land use heterogeneity (entropy index / EI) is as follows: 
$\mathrm{EI}=-\{[\mathrm{R} 1 * \log (\mathrm{R} 1)]+[\mathrm{R} 2 * \log (\mathrm{R} 2)]+[\mathrm{R} 3 * \log (\mathrm{R} 3)]+[\mathrm{K} 1 * \log (\mathrm{K} 1)]+[\mathrm{K} 2 * \log (\mathrm{K} 2)]+$ $\mathrm{K} 3 * \log (\mathrm{K} 3)]+[\mathrm{I} 1 * \log (\mathrm{I} 1)]+[\mathrm{FP} * \log (\mathrm{FP})]+[\mathrm{PK} * \log (\mathrm{PK})]+[\mathrm{TR} * \log (\mathrm{TR})]+[\mathrm{H} * \log (\mathrm{H})]\} /$ $\log (\mathrm{k})$

\section{Information:}

R1: land use percentage of the single-house / coupling / series / townhouses

$\mathrm{R} 2$ : land use percentage of the flats, apartments

R3: land use percentage of the village houses

$\mathrm{K} 1$ : land use percentage of the urban and regional scale of trade and services

K2: land use percentage of the BWK and district scale trade and services

K3: land use percentage of the village and local scale trade and services

I: land use percentage of the industrial

FP: land use percentage of the public service, social facilities

$\mathrm{PK}$ : land use percentage of the government, defense and security facilities

TR: land use percentage of the transportation facilities (terminal, station, port, etc.)

$\mathrm{H}$ : land use percentage of the green open space

$\mathrm{k}$ : number of determined land use categories (in the study amounted to eleven types of land use)

\section{Nearest Neighbor Analysis}

The nearest neighbor analysis method is an analysis to identify the pattern of urban spatial structures and clean water distribution service, quantitatively. The pattern is:
a. uniform,
b. random,
c. clustered

The nearest neighbor indexes are classified into three values that each have a dispersion type $[12,13]$.

a. If $\mathrm{T}=0$ then the dispersion pattern is clustered,

b. If $\mathrm{T}=1$ then the dispersion pattern is random, and

c. If $\mathrm{T}=2.15$ then the distribution is uniform.

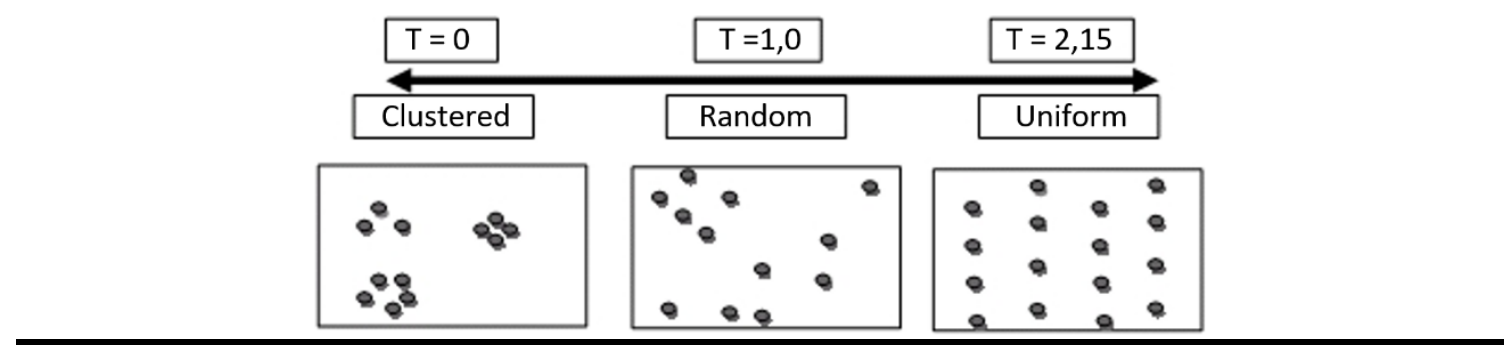

Figure 1. Index and Pattern of Nearest Neighbor Analysis

\section{RESULT}

\section{Ovenview of Jatimulyo Urban Communities}

Jatimulyo Urban Communities, Lowokwaru District, Malang City has an area of 259.75 ha. The northern boundary is Tunggulwulung District, the southern boundary is Penanggungan District, the western boundary is Dinoyo, and the eastern boundary is Mojolangu District. Jatimulyo Urban Communities is located at an altitude of 445 meters above sea level. The typology of Jatimulyo Urban Communities consists of rice fields, cultivation, plantation, animal husbandry, mining/quarrying, handicrafts and small 
industries, medium and large industries and trade and services. Jatimulyo Urban Communities is divided into ten community groups which are divided into 75 neighborhood groups (Kelurahan Jatimulyo, 2016; RRRTRK Malang, 2013)

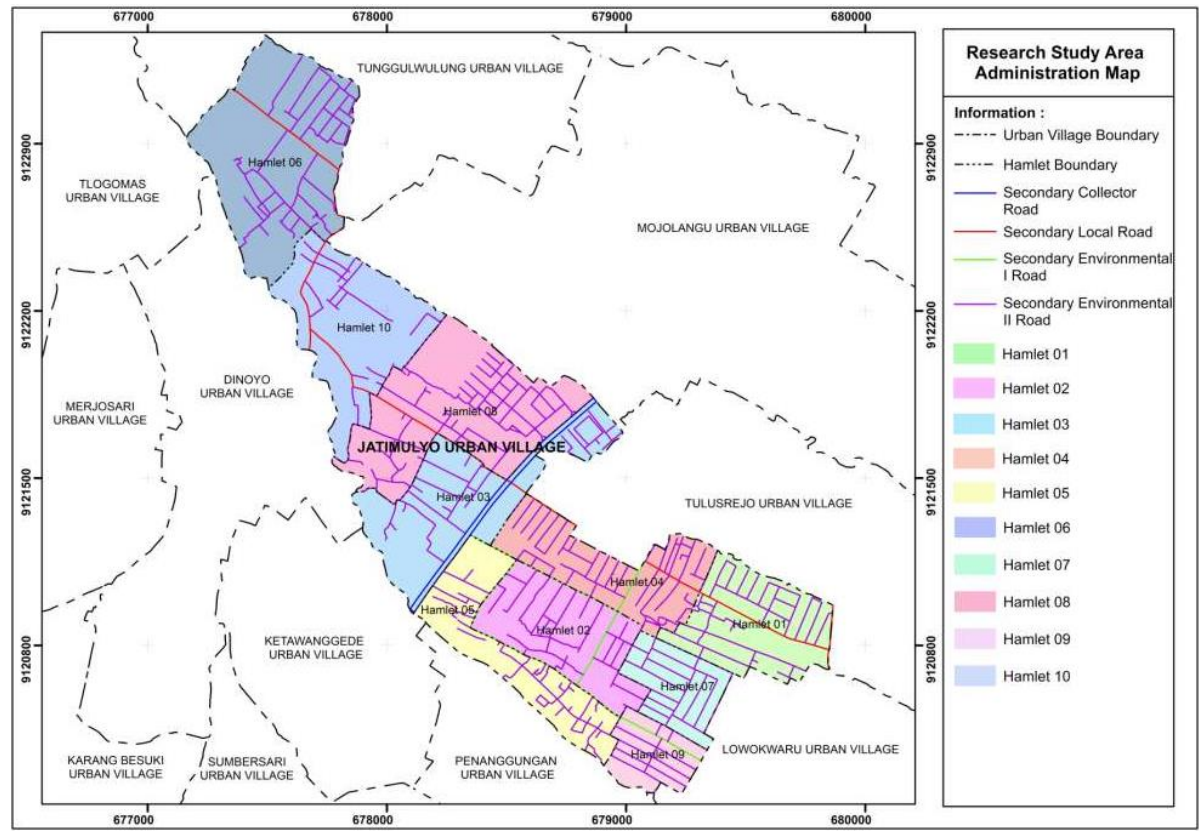

Figure 2. Administration Map of Jatimulyo Urban Communities

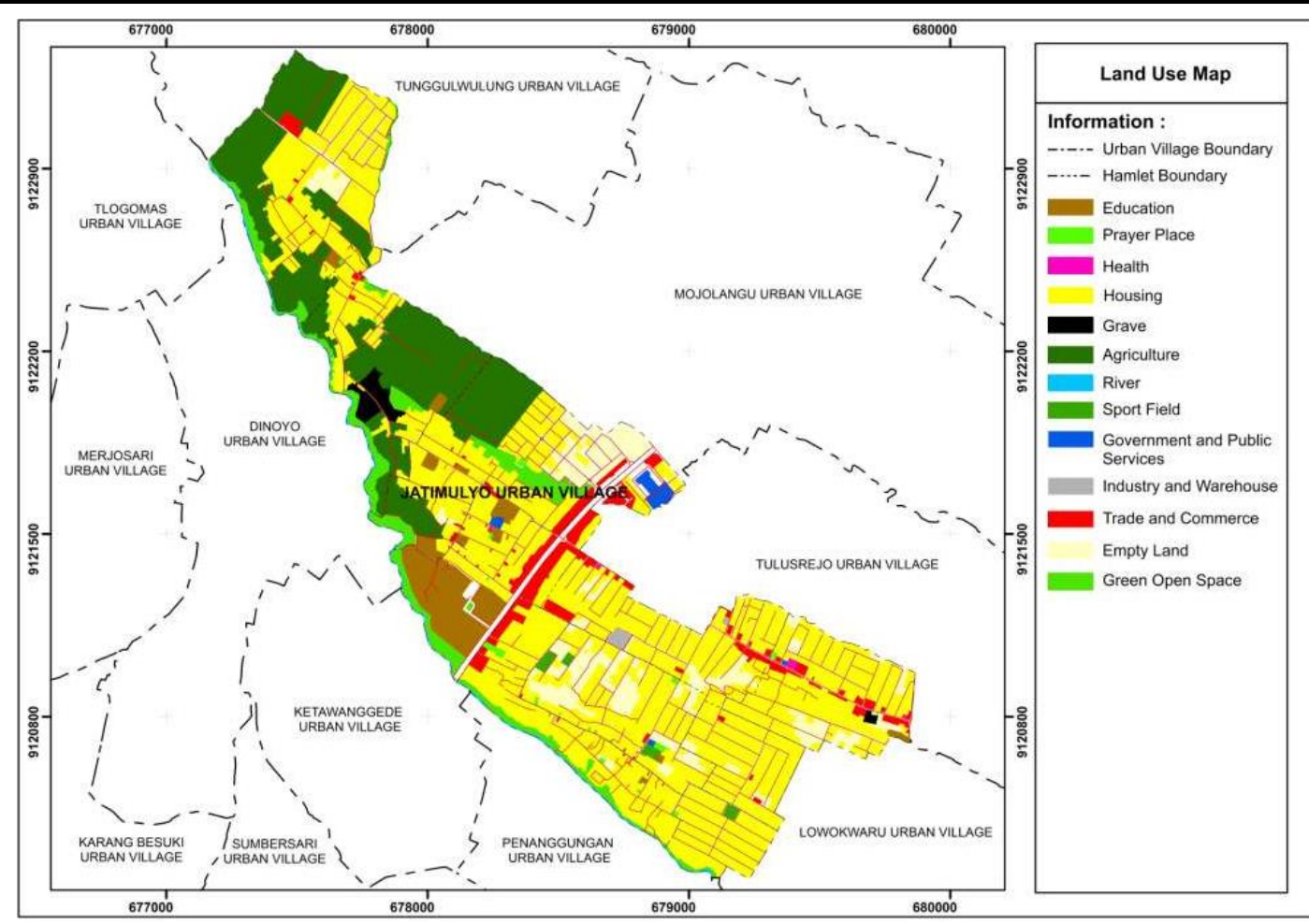


Figure 3. Land Use Map of Jatimulyo Urban Communities

\section{Population and Building Density}

The population in Jatimulyo Urban Communities in 2016 is 21,700 people with the total area of 259.75 ha [16] and has a population density of 83.54 people/ha. Based on the analysis, Jatimulyo Urban Communities has a medium population density. The total number of buildings in Jatimulyo Urban Communities is 5,629 units with the total area of 259.75 ha [16] and has a building density of 21.67 buildings/ha. Based on the analysis, Jatimulyo Urban Communities has a medium building density.

\section{Level of Diversity}

\section{Nearest Neighbor Analysis}

The above figure shows the distribution of public facilities in Jatimulyo Urban Communities in the form of educational facilities, health, government and public services, trade and commerce, prayer place and green open space (RTH). Each public facility is represented by nodes that are interconnected with other nodes that have the closest distance.

The value of $\mathrm{T}$ for the Jatimulyo urban spatial structures is 1.0 indicating the distribution pattern of the facility is random, this is because every public facility in the residential area is uneven, so the distance generated varies. In addition, the settlement area in the south of Jatimulyo Urban Communities is not adequately serviced by public facilities as the public facilities in Jatimulyo Urban Communities are concentrated in the north, causing the distribution of public facilities to become random.

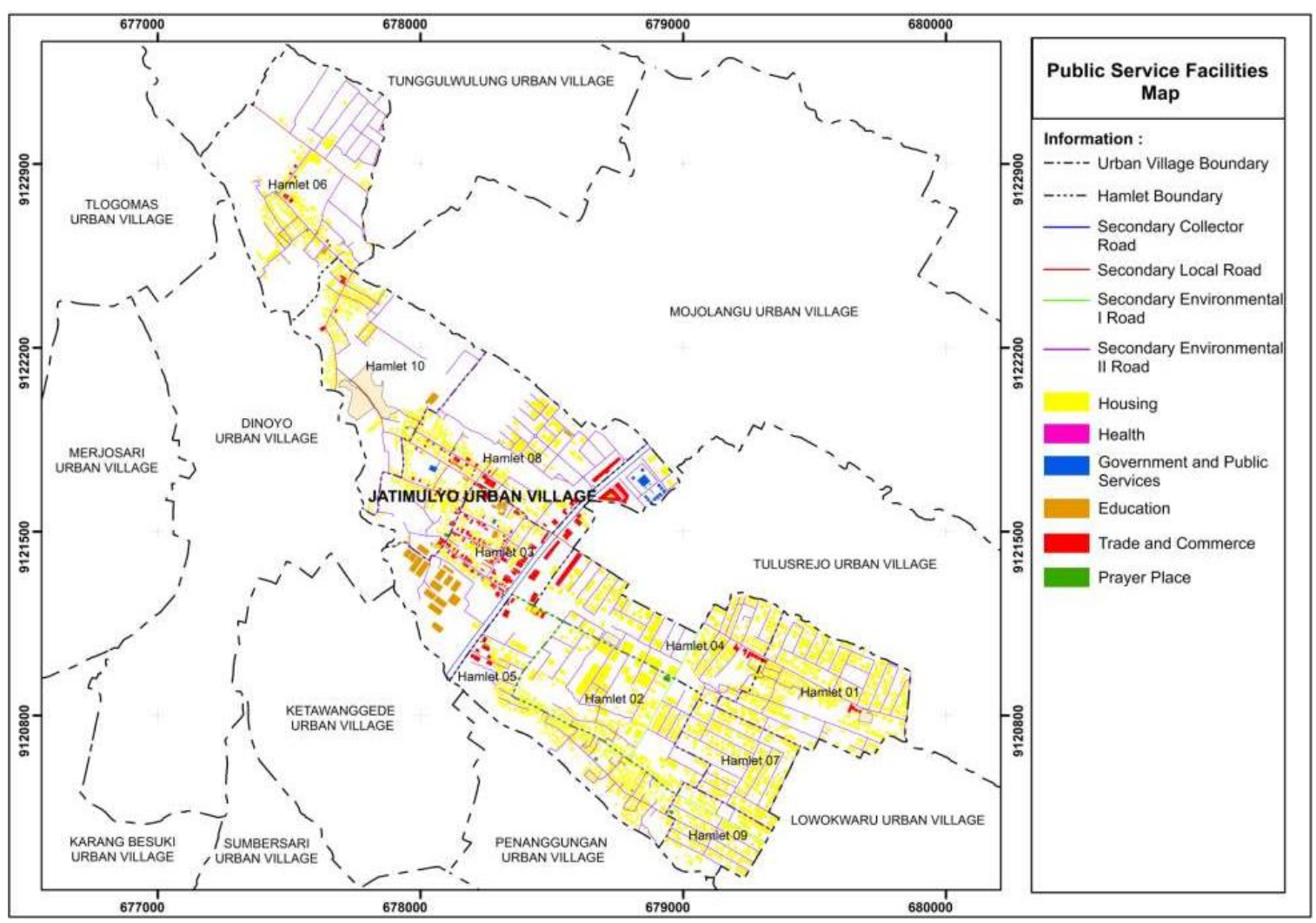

TATA LOKA - VOLUME 21 NOMOR 4 - NOVEMBER 2019 - p ISSN 0852-7458 - e ISSN 2356-0266 
Figure 4. Distribution of Public service facilities Map in Jatimulyo Urban Communities

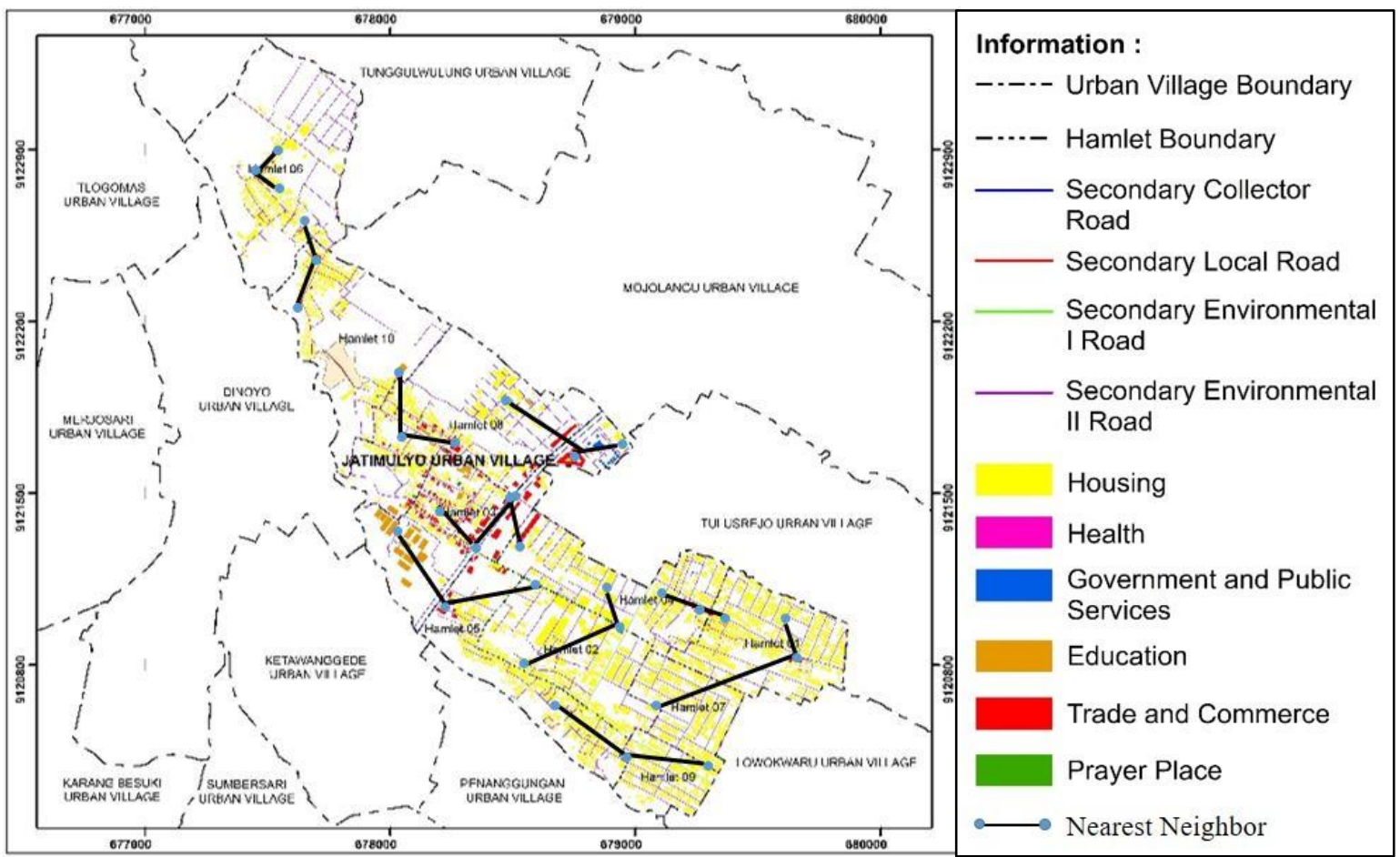

Figure 5. Nearest Neighbor Index of Urban Spatial Structures In Jatimulyo Urban Communities

\section{Entropy Index}

The Entropy Index of Jatimulyo Urban Communities facilities based on the calculation shows the number of 0.51. Jatimulyo Urban Communities is classified as medium diversity, where facilities spread unevenly.

\section{Compactness Level}

From the calculation result, the Gini coefficient obtained from Jatimulyo Urban Communities is 0.99. Judging from the theory (Tsai, 2001) of the Gini coefficient and calculations done, it can be concluded that Jatimulyo Urban Communities has distribution facilities and infrastructure very close to perfect inequality.

\section{Sustainability Level}

Interpretation of the sustainability level of Jatimulyo urban spatial structures is obtained from the calculation using a reference from similar research. Interpretation using similar research is:

a. population and building density (Ministerial Regulation No. 20 of 2011)

b. level of diversity or Analysis of Nearest Neighbors (Bintarto, n.d; Buyong, 2007).;

c. entropy index (Gemilang, 2008); and

d. gini coefficient (Tsai, 2001). 
The calculation and interpretation of similar research shows that the urban spatial structures of Jatimulyo Urban Communities were included in medium sustainability level (101.1-200 people/ha), moderate building density (20-40 buildings/ha), random diversity (10) and entropy index (0.51), and compaction included to very close perfect inequality (Gini coefficient 0.99 ).

Table 2. Analysis of Sustainability Level

\begin{tabular}{|c|c|c|c|}
\hline ASPECTS & & $\begin{array}{ll}\text { JATIMULYO URBAN } \\
\text { COMMUNITIES }\end{array}$ & INTERPRETATION \\
\hline \multirow{2}{*}{ Density } & $\begin{array}{l}\text { Population } \\
\text { Density }\end{array}$ & $\begin{array}{l}\text { Medium Population Density } \\
\text { (101.1-200 people/ ha) }\end{array}$ & $\begin{array}{l}\text { Population density in Jatimulyo Urban } \\
\text { Communities is classified as moderate } \\
\text { density }\end{array}$ \\
\hline & Building & $\begin{array}{l}\text { Medium Building Density } \\
\text { ( } 20-40 \text { buildings /ha) }\end{array}$ & $\begin{array}{l}\text { Building density in Jatimulyo Urban } \\
\text { Communities is classified as moderate } \\
\text { density }\end{array}$ \\
\hline Diversity & $\begin{array}{l}\text { Nearest } \\
\text { Neighbor }\end{array}$ & 1.0 random & $\begin{array}{l}\text { Jatimulyo Urban Communities is classified } \\
\text { as a random category where the spread of } \\
\text { facilities and infrastructure spread to all } \\
\text { village area }\end{array}$ \\
\hline IE & Entropy & 0.51 & $\begin{array}{l}\text { IE of Jatimulyo Urban Communities belong } \\
\text { to medium diversity, where facility spread } \\
\text { unevenly }\end{array}$ \\
\hline Compactness & $\begin{array}{l}\text { Gini } \\
\text { Coefficients }\end{array}$ & 0.99 & $\begin{array}{l}\text { It can be concluded that Jatimulyo Urban } \\
\text { Communities distribution is very close to } \\
\text { perfect inequality }\end{array}$ \\
\hline
\end{tabular}

\section{CONCLUSIONS}

The sustainability level of Jatimulyo Urban Communities, Lowokwaru District, Malang City was found to have the urban spatial structures of Jatimulyo Urban Communities included in moderate sustainability level (101.1-200 people/ha), moderate building density (20-40 buildings/ha), random diversity (1.0) and entropy index (0.51), and compaction including to very close perfect inequality (Gini coefficient 0.99 ).

\section{ACKNOWLEDGMENTS}

The authors acknowledge the Institute of Research and Community Services - University of Brawijaya (Lembaga Penelitian dan Pengabdian Kepada Masyarakat Universitas Brawijaya) for sponsored this research,

\section{REFERENCES}

Korcelli P Kozubek E Piorr A 2011. Economy and Employment. In: Piorr A, Ravetz J, Topics I (Eds) Rural-Urban Regions and Peri-Urbanisation in Europe Academic Books Life Sciences: Copenhagen

Ristime Aki M 2011 Mobility and Transport In: Piorr A, Ravetz J, Topics I (Eds) Peri-Urbanisation in Europe: Pp 61-64. Academic Books Life Sciences: Copenhagen.

Djakapermana R.D 2008 Changes in Spatial Use along Jagorawi Toll Road and Its Implication on Environmental Quality (Reduced Function of Water Infiltration and Its Impact on Land Degradation). Bogor: Bogor Agricultural Institute (Djakapermana R D 2008. Perubahan Penggunaan Ruang Di Sepanjang Jalan Tol Jagorawi Dan Implikasinya Pada Kualitas Lingkungan (Menurunnya Fungsi Peresapan Air Dan Dampaknya Pada Degradasi Lahan). Bogor: Institut Pertanian Bogor)

Azman, Fauzi. 2006. Urban Development Framework in Anticipation of Urban Development Trends. (Azman, Fauzi. 2006. Kerangka Pengembangan Kota dalam Mengantisipasi Kecenderungan Perkembangan Perkotaan.) 
Kentworthy, Jeffrey R. 2006. The Eco-city: Ten Key Transport Planning Dimension for Sustainable Development. Environment and Urbanization. Vol 18, No.1

Ministerial Regulation No. 20 of 2011 for Guidelines of Detailed Urban Spatial Plan (Peraturan Menteri Nomor 20 Tahun 2011 Tentang Pedoman Penyusunan Rencana Detail Tata Ruang Kota)

Yosef Rafeq Jabareen. 2006. Sustainable Urban Forms: Their Typologies, Models, and Concepts. Journal of Planning Education and Research. 26:38-52. Association of Collegiate Schools of Planning and Massachusets Institute of Technology

Jacobs, Jane. 2002. The Uses of Sidewalks: Safety from the Death and Life of Great American Cities dalam The City Rider (editor Richard T.Le Gates dan FredericStout). Routledge, Taylor \& Francis Group. London and New York.

Acioly, Claudio C. Jr. 2000. “ Can Urban Management Liver in Sustainable City? Guided Densification in Brazil versus Informal Compactness in Egypt”.

Tsai, Yu-hsin. 2001. Travel-Efficient Urban Form: A Nationwide Study of Small Metropolitan Areas, The University of Michigan.

Gemilang, A Akhmad. 2008. Spatial Pattern Analysis of Makassar City South Sulawesi Land Use. Bogor: Bogor Agricultural University (Gemilang, A Akhmad. 2008. Analisis Pola Spasial Penggunaan Lahan Kota Makassar Sulawesi Selatan. Bogor: Institut Pertanian Bogor)

R. Bintarto and Hadisumarno. 1991. Geographic Analysis Method, (LP3ES). Jakarta (R. Bintarto dan Hadisumarno. 1991. Metode Analisis Geografi, (LP3ES). Jakarta.)

Buyong, Taher. 2007. Spatial Data Analysis For Geographic Information Science, Johor Bahru. Kuala Lumpur: University of Technology Malaysia.

Lowokwaru District in Figures Year 2016 (Kecamatan Lowokwaru Dalam Angka Tahun 2016)

Jatimulyo Urban Communities Profile Year 2017 (Profil Kelurahan Jatimulyo Tahun 2017)

Review Of Detailed Spatial Plan Of Malang City (Urban Area Of North Malang) Year 2013 (Review Rencana Rinci Tata Ruang Kota Malang (Bagian Wilayah Perkotaan Malang Utara) Tahun 2013) 